\title{
Redaksjonelt
}

\section{Om flere nye artikler, redaktørskifte og ADNOs videre drift}

I mai og juni publiserte ADNO fire nye artikler som tematisk spenner fra praksisveiledning og studenters deltakelse i forskning i lærerutdanningen til statlig og kommunal styring av norsk utdanningspolitikk og lærebøker i norsk i møte med et nytt hovedområde i faget. De bekrefter dermed en utvikling mot stadig større tematisk bredde i tidsskriftet. Her følger en kort introduksjon til artiklene, før jeg takker for meg med et oversyn over ADNOs utvikling 20072009.

"Om praksisopplæring i norsk allmennlærerutdannelse. En artikkel i NYMYprosjektet" av Kaare Skagen presenterer to nyere studier av praksisveiledningen ved tre praksisskoler der bruk av individuell veiledning og gruppeveiledning samt fokus på innholdet i veiledningen varierte. Studiene konkluderer med at det fortsatt er avstand mellom teoridelen og praksisdelen i allmennlærerutdanningen. Funnene diskuteres i lys av veiledningsteori og annen forskning. God dokumentasjon på hvordan erfarne lærere lykkes i skolehverdagen, kan skape grunnlag for en pedagogikk som formidler realistiske bilder til inspirasjon for både lærerstudenter og øvingslærere, skriver Skagen, og peker på behovet for systematiske studier på dette feltet.

Det er med både glede og vemod vi presenterer artikkelen "Forholdet mellom stat og kommune i styring av norsk utdanningspolitikk 1970 - 2008" av Øystein Engeland og Gjert Langfeldt. Engeland gikk bort i fjor sommer etter lengre tids sykdom. Artikkelen representerer hans siste forskningsinnsats. Den bygger på hans tidligere arbeider og trekker opp nye perspektiver. Gjert Langfeldt har sluttført artikkelen. Sammen peker de på at nasjonal styring av norsk utdanning har økt på bekostning av det lokale selvstyret, særlig etter 2000, og at det nasjonale nivået er i ferd med å etablere et omfattende styringsgrep på skolesiden. Det nye er at dette skjer innenfor en ordning hvor inntektssystemet gir kommunene ansvar for undervisningen, og hvor statens mulighet til å bruke økonomiske styringsmidler er redusert, påpeker forfatterne.

«Det finnes det vel ikke noe forskning på?» er tittelen på en artikkel av Lars Anders Kulbrandstad. Spørsmålet ble stilt av norskstudenter som gjorde sine første forskererfaringer ved lærerutdanningen ved Høgskolen i Hedmark, og artikkelen presenterer "Et eksempel på studentinvolvering i forskning", som undertittelen sier. Hittil er lite publisert om erfaringer fra slik studentmedvirkning. Artikkelen rapporterer fra et prosjekt der fire allmennlærerstudenter deltok i utprøving av et opplegg for innsamling av data om språkholdninger og språkkunnskaper blant ungdomsskoleelever. Studentene fikk grunnleggende faglig og metodisk opplæring, var med og utviklet instrumenter for dataelisitering, gjennomførte selve innsamlingen og medvirket $\mathrm{i}$ bearbeidingen og analysen av data og rapporteringen av funn. Artikkelen presenterer resultater fra 
utprøvingen av instrumentene, evaluerer erfaringene med studentenes involvering i forskningsprosjektet og diskuterer noen utfordringer med det.

"Læreboka - ein garantist for læreplannær undervisning?" spør Magne Rogne, og temaet er "Norskbøkene i møte med eit nytt hovudområde". Hovedområdet det dreier seg om, er sammensatte tekster, et felt som også ble belyst $\mathrm{i}$ hans artikkel "Mot eit moderne norskfag" i ADNO 2008. Ved hjelp av begrep fra sosialsemiotisk teori og refleksjoner rundt lærebokas avgrensede mediale rammer analyseres fire sentrale lærebøker i norskfaget for å få fram i hvilken grad de samsvarer med det nye hovedområdet. Artikkelen konkluderer med stor variasjon mellom lærebøkene, men de har det til felles at de er særlig svake på feltet digitale tekster. Derfor mener Rogne undervisningen i langt større grad enn tidligere må frigjøres fra lærebøkene dersom elevene skal nå kompetansemålene i læreplanen i norsk.

Den 4. juni ble det avholdt møte i redaksjonsrådet i ADNO. Der ble Ove Haugaløkken, PLU, NTNU, gjenvalgt som leder for rådet. Det ble vedtatt at den videre driften av tidsskriftet $i$ to år framover fortsatt vil skje fra Institutt for lærerutdanning og skoleutvikling, $\mathrm{UiO}$, og endringer i redaksjonen ble godkjent. Else Askerøi, Høgskolen i Akershus, fratrer som seksjonsredaktør for det yrkespedagogiske feltet. Hun har vært med i redaksjonen fra starten av og har lagt ned et stort arbeid i publiseringen av flere artikler. Nå går hun av for aldersgrensen. Else skal ha takk for en verdifull innsats i redaksjonen i den viktige oppstartsfasen. June Tolsby, også Høgskolen i Akershus, overtar som seksjonsredaktør etter Else, og Glenn Ole Hellekjær, ILS, trer inn som seksjonsredaktør i språkdidaktikk.

Fra 1. august overtar Jon Magne Vestøl som ansvarlig redaktør for tidsskriftet. Han har vært med fra starten av som seksjonsredaktør for det religionsdidaktiske feltet, og i fjor publiserte ADNO hans artikkel "Didaktiske modeller i lærerutdanningen. En analyse av lærerstudenters praksisrefleksjon". Med Vestøl som ansvarlig redaktør er jeg trygg på at ADNO vil utvikle seg videre som et leseverdig og faglig oppdatert tidsskrift for fagdidaktikk og lærerutdanning.

Før jeg takker for meg som ansvarlig redaktør, er det på sin plass med en kort oppsummering av ADNOs utvikling fra starten i 2007 til i dag.

Artikkelvolumet har økt gradvis fra fem fagfellevurderte artikler ved starten i oktober 2007, til åtte i 2008, og med like mange artikler publisert første halvår i 2009 ligger dette an til å bli et produktivt år for ADNO. Redaksjonen må ikke lenger henvende seg til forfattere for å få inn manus til vurdering. Det er en god utvikling. Fra og med 2008 publiseres artiklene fortløpende i årganger, noe som reduserer publiseringstiden og er en av fordelene ved elektronisk publisering. Samlet tid for fagfellevurdering og redaksjonell vurdering har i 2008 og i år vært ca. 60 dager. Noen artikler publiseres uten store endringer, andre krever omfattende omarbeiding. Når antall dager fra innsending av manus til utgivelse av artikkel var 107 i 2007, 189 i 2008 og 90 i 2009 gjenspeiler dette i hvilken grad artikkelmanusene krevde omarbeiding. Totalt er 35 artikkelmanus fagfelle- 
vurdert fra 2007 til i dag, 21 av disse er publisert, og noen er under omarbeiding eller publisering, mens de øvrige er avvist. ADNO har i vurderingsprosessen kunnet støtte seg på en rekke høyt kvalifiserte fagkonsulenter fra universitet og høgskoler i hele landet og i nabolandene. De har gjort en uvurderlig innsats for tidsskriftet.

ADNOs første utgave inneholdt et knippe artikler om RLE-faget og 2. fremmedspråk, didaktikkbegrepet, PISA og språklige minoriteters skoleprestasjoner. I 2008 ble profilen preget av språkdidaktiske artikler, uten at dette kom som følge av noen planlagt satsning fra redaksjonens side, i tillegg til artikler om RLE-faget, didaktikkbegrepet og lærerutdanning. Hittil i år er fortsatt fagdidaktiske emner godt representert, nå med større faglig bredde, i tillegg til flere artikler om lærerutdanning. Hvis denne utviklingen fortsetter, vil 2009årgangen kunne markere ADNO som et tidsskrift for fagdidaktikk og lærerutdanning i tråd med intensjonene for tidsskriftet.

Forfatterne var i 2007 både etablerte og nyere forskere som representerte praktisk-pedagogisk og annen utdanning. I 2008-årgangen og så langt i år har de etablerte forskerne dominert, de fleste med bakgrunn fra allmennlærerutdanningen, de øvrige fra praktisk-pedagogisk eller annen utdanning. To forfattere står for to artikler hver, og begge er stipendiater. I perioden har også tre artikler vært sampublikasjoner.

Mens artiklene i 2007 var teoretiske, drøftende eller oversiktartikler, lå hovedvekten på drøftende og empiriske artikler i 2008, i tillegg til noen få teoriog oversiktsartikler. Hittil i år dominerer drøftende og empiriske artikler helt. Dette vil igjen kunne endre seg. Som et nasjonalt tidsskrift publiserer ADNO artikler på norsk, men det er også publisert en artikkel på svensk og tre artikler på engelsk. De siste har alle handlet om engelskfaget. I 2007 ble det publisert en debattartikkel, og i 2008 og 2009 kom bokomtalene med. Tidsskriftet har et potensial for å bli et forum for fagdidaktisk og pedagogisk debatt og for omtale av viktig faglitteratur.

Jeg vil takke alle som har bidratt til utviklingen av ADNO så langt: Takk til redaksjonsrådet for støtte og for tilliten som er vist meg! Takk til redaksjonen for stor arbeidsvilje og godt samarbeid! Takk til fagkonsulenter og forfattere for alle kvalifiserte bidrag! Sist, men ikke minst, takk til redaksjonsleder Karl Henrik Flyum som har vært min "høyre hånd" og gode rådgiver i ett og alt!

Så ønsker jeg den nye redaktøren, Jon Magne Vestøl, til lykke med den videre utviklingen av tidsskriftet!

Oslo, juli 2009

Rita Hvistendahl

Ansvarlig redaktør 